International Journal of

Urban and Regional Research

\title{
Raising the regional Leviathan: a relational-materialist conceptualization of regions-in-becoming as publics-in- stabilization
}

\begin{tabular}{|c|c|}
\hline Journal: & International Journal of Urban and Regional Research \\
\hline Manuscript ID: & IJURR-Art-1093.R2 \\
\hline Manuscript Type: & Article \\
\hline $\begin{array}{r}\text { Please choose one or two } \\
\text { subject categories that best } \\
\text { describe the article's concerns: }\end{array}$ & $\begin{array}{l}3 \text { Regional development, government \& policy, devolution, industrial policy, } \\
\text { labour markets, economic migration, tourism, } 7 \text { Theoretical debates \& } \\
\text { reviews (state, neoliberalism, consumption sector, new industrial spaces) }\end{array}$ \\
\hline Keywords: & $\begin{array}{l}\text { regions, regionalization, institutionalization, publics, issues, stakeholders, } \\
\text { materialization }\end{array}$ \\
\hline $\begin{array}{r}\text { Which world region(s) does the } \\
\text { article focus on? Select up to } \\
\text { five.: }\end{array}$ & $\begin{array}{l}\text { Europe < World Region, EU < World Region, Eastern \& } \\
\text { Central Europe/Balkans < World Region, Non-place specific }<\text { World } \\
\text { Region }\end{array}$ \\
\hline $\begin{array}{r}\text { Which country/countries does } \\
\text { the paper focus on? Select up } \\
\text { to five.: }\end{array}$ & $\begin{array}{l}\text { Sweden < Europe (Western) < Countries, Denmark < Europe (Western) }< \\
\text { Countries, Estonia < Europe (Eastern \& Central) \& Balkans < Countries, } \\
\text { Finland < Europe (Eastern \& Central) \& Balkans < Countries, Poland }< \\
\text { Europe (Eastern \& Central) \& Balkans < Countries }\end{array}$ \\
\hline $\begin{array}{r}\text { Which city/cities does the } \\
\text { article focus on? List up to five } \\
\text { cities.: }\end{array}$ & Stockholm, Malmoe, Copenhagen \\
\hline
\end{tabular}




\title{
Raising the regional Leviathan: a relational-materialist conceptualization of regions-in-becoming as publics-in-stabilization
}

\author{
Jonathan Metzger, KTH Royal Institute of Technology, Division of Urban and Regional Studies, \\ Department of Urban Planning and Environment, Stockholm, Sweden.
}

\begin{abstract}
The purpose of this paper is to contribute to the understanding of how spatial entities in general - and those spatial entities that are defined as 'regions' in particular - form, evolve and sometimes stabilize. Inspired by the scholarship of Noortje Marres the paper explores how regions in becoming may be gainfully conceptualized as publics in stabilization. In the paper it is argued that some of the mechanisms involved in such processes pertain to how territorially framed issues sometimes become formulated as loosely articulated propositions for regionalization. These can with time generate emergent stakeholder communities which in turn may become stabilized and delegated to more durable forms and materials and finally naturalized as recognized regions. A suggested conceptual model is utilized to perform an analysis of empirical material from three contemporary processes of regionalization in Northern Europe with the purpose of examining and discussing some of the potential merits and shortcomings of the conceptual model. It is concluded that adopting the proposed perspective can enable scholars to highlight some of the mechanisms whereby vague and non-coherent propositions for regionalization within time may be singularized and stabilized to such a degree that they become taken for granted as naturalized spatialities.

Keywords: regions, regionalization, institutionalization, publics, issues, stakeholders, materialization
\end{abstract}

Acknowledgements: I wish to extend my gratitude to the anonymous referees for their helpful and supportive comments. A protean version of this paper was presented at the AESOP annual conference in Helsinki, $7-10^{\text {th }}$ of July 2010. Earlier versions of the paper have further benefitted from generous and helpful comments from Frida Andersson, Beatrix Haselsberger, Patsy Healey, Jean Hillier and Gunnar Olsson -who have all helped me greatly in clarifying and thinking through my arguments. Special gratitude is extended to Jonas Bylund whose acute reading of a late version of the paper helped me find ways to navigate some dire straits. Of course, none of them bear any responsibility for the lapses, errors and misinterpretations still in the paper. The research presented in this paper was financed by FORMAS assistant professorship grant \# 250-2009-1187. 


\section{Introduction}

In an important commentary on the surprising persistence and mutability of the concept of 'the region' Paasi (2010:2296) has noted that in the seemingly endless scholarly debate concerning the ontological status of regions ('are they constructed or not?'), it at present appears as if the idea of the region as a 'social construct' has become close to an axiomatic truth. Nevertheless, Paasi observes that it is very often unclear what is meant by this statement and further - if the region is a social construct - how, by whom, and through what materials is it constructed in practice? Or posed differently: how do regions become? Taking Paasi's questions as a cue, the purpose of this paper is to contribute to the understanding of how spatial entities in general - and those spatial entities that are defined as 'regions' in particular - form, evolve and (sometimes) stabilize. Following Latour (1988:185) the launching point of this paper is the suggestion that regions do not hold together because they are "really out there". Rather, because they (sometimes) hold together, we say they are really out there. The questions asked in this paper thus do not concern whether regions are constructed or not but rather how regional constructs may come to last and even become taken for granted, by asking following Munk \& Abrahamsson (2012): "how does it hold together, how does it endure, how does it come to appear as singular?".

In what is generally recognized as one of the most influential social constructivist accounts, Allen et al's Rethinking the region, it is stated that a region should be seen as a "product of a particular combination and articulation of social relations stretched over space" (Allen et al, 1998:143, emphasis added). Both drawing on and diverging from this basic definition, this paper will ask what can be gained in our understanding of regions and regionalization processes if we jettison the qualifier [social] from the above definition, or at least reconceptualize the 'social' as not only having to do with linguistic and symbolic practices but also encompassing the concrete association of such heterogeneous non-human components as bridges, motorways, maps, legal code, tourist brochures and railway ticketing systems. Again, building on Latour's argument (1988), we may come to see that regions stabilize and endure precisely because they hold on to many things -thus tying their fate to anything at hand that is more solid than mere fleeting words, and thereby further putting the materiality or materialization of stabilized regions into central research focus.

The conceptual model developed in the paper will be based upon a drawing-together of elements from human geographical theories on regions and regionalization, planning research on practices of placemaking and strategic planning and the array of relational-materialist research practices often referred to 
as Actor-Network Theory (ANT). The paper also engages with so-called 'after-ANT' thinking on spatiality and the construction of durable (spatial-ized) entities, and ANT-related political theory on the interplay between processes of issue formation and the emergence of publics, as developed in the work of Noortje Marres.

Finding their inspiration with Callon \& Latour (1981), Metzger \& Schmitt (2012) have suggested that a regionalization process can be likened to the raising of a 'regional Leviathan'. Following Hobbes (1651/1997) and Callon \& Latour (1981) a 'Leviathan' can be understood as a relationally constituted entity made by and partially made up from humans which is brought into being through a process whereby "the many have become one, and are increased by one" (Stengers quoted in Haraway, 2008: 244; see also Cooren, 2010:167), that is: as the relational constitution of an emergent effect through which a new semi-autonomous entity, which adds up to more than the sum of its constituent parts, comes to populate the world. In this paper this analogy will be further explored and developed: if the region is an entity constructed by humans, yet not wholly human in its constitution - by what mechanisms, processes and through what materials may such a collective (and collecting) being come into existence? Inspired by the scholarship of Marres (2005a, 2005b) this paper explores if the raising of such regional Leviathans may be gainfully conceptualized as the stabilization of issue-centered publics given that we allow ourselves to re-articulate the concept of 'the public' along the lines suggested by Marres so as to go beyond the conventional idea that these must by necessity be made up only of 'locals' or laypersons, and instead allow the concept to encompass the full motley assortments of heterogeneous and geographically potentially dispersed actors that become attached to a specific issue or problem. It is argued that the conceptualization of regions-in-becoming as publics-in-stabilization can enable investigators of processes of regionalization to identify and highlight important aspects of such processes that might otherwise be difficult to conceptualize, articulate or discuss - particularly pertaining to the mechanisms through which regions become stabilized into taken-for-granted realities. It may particularly serve the purpose of not only highlighting the processual and contingent character of regions but also to enable a discussion on the entangled interplay between elements often labelled as on the one hand human and/or 'discursive' and on the other hand non-human and/or 'material' in the unfolding of the processes where-through the entities we come to know as regions emerge.

In the paper ANT is approached as an "adaptable, open repository" of concepts that may be used to "tell cases, draw contrasts, articulate silent layers, turn questions upside down, focus on the unexpected, add to one's sensitivities, propose new terms, and shift stories", and "not to purify the repertoire, but to 
enrich it" (Mol, 2010). Thus, this paper has no ambition of 'applying ANT' to the subject of regionalization. Rather it attempts to explore and tinker with some components of the broad conceptual repertoire which over the years has developed in the broader context of ANT scholarship, and more generally to experiment with the radical relational-materialist ontology that has been cultivated in ANTrelated research. Relational materialism can in the most general terms be described as an ontology that skirts any a-priori distinction between 'social' or 'material' (or 'discursive', 'cultural', 'economic', 'technological', etc) aspects of unfolding worldly events and instead prompts the researcher to empirically explore the heterogeneous linkages between elements regularly slotted into these different categories. According to John Law, relational materialism thus "effaces the analytical divisions between agency and structure, and the macro- and the micro-social, but it also asks us to treat different materials - people, machines, 'ideas' and all the rest - as interactional effects rather than primitive causes" (Law, 1992: 389). It invites the tracing and mapping of 'coming-togethers' of diverse elements and materials, and how the relations between these elements appear to make a difference in the unfolding of events. Some particular such relations may be unique and contingent to a situation at hand, while other mechanisms may appear to be more stable and to have repeated, recognizable or reproducible effects across contexts under certain specific circumstances or conditions. From such a position it makes little sense for the social scientist to attempt to uncover some primus motor behind specific developments, and instead invites a focus on how things come together, sometimes repeatedly, to produce more or less specific, unique and/or repetitive or stable effects. This paper aims to broadly explore how such an ontological intuition may potentially provide new insights and tools for studying the formation, evolution and stabilization of the lumps of partially stabilized heterogeneous relations that sometimes come to be taken for granted as natural and self-evident 'regions'.

In addition to this introduction the paper consists of four main sections. In the next section a selection of human geographic and planning studies literature on regionalization is drawn-together with elements of ANT and 'after-ANT' theory, to function as a launching point for the argument presented in the sections that follow. Departing from the broad poststructuralist approach to spatial entities, the trope of the Leviathan is mobilized to discuss how a relational-materialist/ANT take on spatial entities diverge from more common social constructivist strands of regional theory, a difference which particularly boils down to the question of the importance of materiality. It proceeds to discuss the mechanics of regionalization processes from a relational-materialist perspective, arguing that we in such process can see how regions are institutionalized through the delegation of initially vague propositions for regionalization into more durable material forms which eventually may come to stabilize the region to such a degree that it 
becomes a taken-for-granted or seemingly self-evident reality. Building upon the sensibility and concepts introduced in the previous section, the third section of the paper outlines a proposed conceptual model of regionalization processes which is based upon the apprehension of regions-inbecoming as publics-in-stabilization - sketching a roughly sequential order of different mechanisms of stabilization and alignment that appear to often come into play in regionalization processes. The fourth section of the paper applies the previously presented conceptual model to three quite heterogeneous empirical cases, representing contemporary processes of regionalization in Northern Europe, with the purpose of teasing out some of the merits and shortcomings of the presented model. This section also contains an 'empirical postscript' which, building upon material from the empirical cases, discusses the position of the model in relation to the immense complexity and unpredictability of regionalization processes. In the final section a concluding discussion collects, recapitulates and further reflects upon the previously presented arguments - also pointing the way towards the need for further research.

\section{The formation of the regional Leviathan}

Within poststructuralist spatial theory it is often argued that territorial entities such as regions don't come into the world neatly bundled, wrapped up and packaged. Rather, they can be seen as spatiotemporal frames established through intensive labours and political interventions (Callon \& Law, 2005; Painter, 2008; see also Jessop, 2006). Activities of spatiotemporal framing establish relations of inclusion and exclusion, sameness and otherness - and thus function to ascribe what is to be considered to be on the "inside" and "constitutive outside" of a specific, named spatial entity (cf. Hillier 2007 and specifically concerning regions also Syssner, 2006) [FOOTNOTE 1]. Instead of a-priori ontologically given "structured coherences" (cf. the discussion about Aydalot, 1976 in Jessop, 2006) there are all sorts of semi-structured and (with great effort) semi-bounded parts that can be bundled and hedged up in all sorts of ways, and where the specific principle, method or technology for bundling, hedging or articulating the region will produce different effects in the world, depending on how it is performed (Painter, 2008). In relation to regions, particularly Anssi Paasi (e.g. 1986, 2002a, 2002b) has relentlessly highlighted how processes of regionalization are always interventions in the world through which the drawing up of boundaries tacit and explicit, internal and external generate effects of inclusion and exclusion in relation to a particular spatial entity.

ANT can in the broadest sense perhaps be labelled as a specific variant of such a poststructuralist approach (cf. Murdoch, 2006). It originally emerged in the field of Science and Technology Studies in the 1980 s and has since then achieved some degree of impact in the wider social sciences, perhaps 
especially in human geography (including influential works by e.g. Thrift (1996), Whatmore (2002) and Massey (2005). Still, with regards to the study of regions ANT has still so far had only a limited impact even though some contemporary approaches clearly draw inspiration from or display an intellectual family resemblance to an ANT-like sensibility (see e.g. Gibson, 2001; Donaldson, 2006; Healey, 2007 Painter, 2008).

One of the earliest sketches of an embryonic ANT research approach and explicitly relational materialist ontology that appeared in English was in a book chapter from 1981 by Michel Callon and Bruno Latour with the title Unscrewing the big Leviathan: how actors macro-structure reality and how sociologists help them to do so. In the text Callon \& Latour discuss Thomas Hobbes' classical account concerning the emergence of the state as a Leviathan, an "Artificiall Animal" or collective entity through a contractual arrangement whereby a sovereign is authorized as the singular legitimate voice and sole representative of a previously cacophonically chattering and strife-ridden multitude. What Callon \& Latour note to be the highly original contribution of Hobbes is that in his account the sovereign is not above the people, it is "the people itself in another state" an "artificial body" which stands in for "the sum of the multitude's wishes". Thus, to Hobbes "the Leviathan says nothing on its own authority... [n]othing without having been authorized by the multitude, whose spokesman, mask-bearer and amplifier he is" (278).

Callon \& Latour extend Hobbes' concept of the Leviathan to include not only the state per se but all types of societal macro actors, arguing that far from being a self-sufficient "totalitarian monster" a Leviathan can rather be conceptualized as a relationally constituted, semi-autonomous macro-entity-a connector or relay composed of many other connectors or relays an actor "made to act by many others" but also acting back on them (Latour, 2005b:46, see also Paasi, 2010) - and which comes into existence through complex series of "negotiations, intrigues, calculations, acts of persuasion and violence, thanks to which an actor or force takes, or causes to be conferred on itself, authority to speak or act on behalf of another actor or force" (Callon \& Latour, 1981: 278). The singular voice of the Leviathan may thus shut up the babble of the multitude and the many come to appear as a single entity - but only with great effort, investments and upkeep. The emerging Leviathan, as the concomitant formation of a mouthpiece and body politic, is thus constituted through power and produces sometimes fearfully powerful effects - but cannot be explained through pointing to a priori existing 'interests'. Rather, its formation entails the processes whereby new collective (and collecting) interests are formed and stabilized. Examining the formation of a Leviathan thus necessarily entails an exploration of the concrete 
mechanics of how societal power emerges rather than resorting to power as a deus ex machina explanatory variable.

The above given account of Callon \& Latour's discussion about the Leviathan as a collective (and collecting) macro-actor would if applied to the study of regions and regionalization processes generally chime well with by now established broadly social constructivist strands of research on regions and regionalization processes (see e.g. Paasi, 1986; Allen et al, 1998; McLeod \& Jones, 2001). Still, a major divergence between a general social constructivist approach to the study of regions and an alternative approach inspired by Callon \& Latour would be the latter's insistence on the fundamental importance of investigating and highlighting the materiality of regional macro-actors or Leviathans. If materiality only figures vaguely, if at all, in social constructivist analyses of regions and regionalization processes, for Callon \& Latour this aspect takes centre stage. Callon \& Latour thus ask themselves: if there is ontological integrity or stability to a Leviathan, how do the macro-actors we observe in the world become so seemingly solid and durable? The answer they give is that they, even if constructed by humans, do not only consist of humans but also more "durable materials", thus "replacing unsettled alliances" with "walls and written contracts" (284). As Latour notes in a later text (2005a), the stabilized Leviathan is not only made up of people but is "thick with things... an immense complex technology of gathering, meeting, cohabiting, enlarging, reducing and focusing". So if not a monster, the Leviathan is still a motley entity indeed - a heterogeneous assemblage of partially congealed speech acts, legal code, emotional attachments, concrete, bricks, railway tracks, fiber-optic wire, planning documents, and so on - the emergence of which proceeds through the assembly of disparate materials and chiasmic ontological transformations: loose talk about what can and should be transposed into concrete and metal - and back again (cf. Olsson, 2007).

Even though focus on materiality is paramount for Callon \& Latour this does not in any way imply that their approach discounts the role of language as in any way secondary to other factors. Rather, language here figures as an ordering and organizing supplement in the world, a connector which holds together a macro-actor such as a region and supplements it with a proper name (Latour, 1988). But this does in no way imply that it exists only in language or as "discourse", nor that discourse is the only type of glue that can be used to compose the region. This would indeed be a very weak Leviathan. Instead, we must see the proper name and related linguistic practices as one specific type (among many) of connectors or relays that link up all sorts of heterogeneous materials, not in the form of 'representation' but as association and translation, and as a form of order- and coherence-generating 'glue' that functions to 
'lasso', grasp and glean out apparent or potential dimensions and circuits of coherence out of complex entanglements and multiplicities (see also Latour, 2003 and further Olsson, 2007). The weakness of linguistic statements as connectors is that they are highly prone to second-order capture, active rearticulation and/or unintended translational drift. Therefore the highly fluid connections performed through discursive statements can often be stabilized to a higher degree when transposed to more durable materials (see further below).

\section{The articulation of propositions for regionalization: capture, connection, organization}

To put regions more clearly in focus and begin to explore how the above sketched relational-materialist perspective might grant us new purchase on these issues we may experiment with taking as our point of departure the intuition that regions as we come to meet them 'out there in the real world' - the already existing regional Leviathans - always are the results of regionalization processes. Here it is therefore proposed that we should find inspiration with Stengers $(2011)$ and Latour $(1999,2004)$ and use the term proposition for regionalization when discussing processes towards regionalization - to remind us of the fundamental poststructuralist insight that a certain frame of regionality being put forward is always at least potentially in contestation with alternative ways of partitioning, bundling and hedging the world. Some other pertinent qualities of the proposition are, in the context of this paper, that propositions can be either accepted or declined (an aspect which is further developed below), and also that propositions have to be articulated - that is: given a syntactic form by connecting bits and pieces together into a (seemingly) coherent, comprehensible and supposedly desirable suggestion. Since the establishment of regionality from this perspective always involves a process of regionalization through the formulation of a proposition for regionalization, regionality can be described as a property that is enacted (Law, 2004) or performed through various heterogeneous practices and interventions in the world (Donaldson, 2006; Gregson \& Rose, 2000; Law, 2007, 2009). Ascribing regionality - proposing a region - is thus a way of intervening in the world, a proposition for a particular way of organizing a part of the world, always in direct or indirect competition with other possible alternatives. Thus, the ascription of regionality is always deeply political, in the meaning that it carries power and potentially - when successful - can have radical repercussions on the organization and distribution of resources, rights and entitlements and many other aspects of collective and personal life.

The one drawback of using the descriptor 'proposition' for that-which-may-become-established-as-aregion is that this noun may be read as implying some form of first-order action or primary motion. But of course, propositions for regionalization never emerge in a vacuum, but in media res of a world 
always-already going-on -overflowing with other complementary, competing and/or partially overlapping propositions for regionalization both under the same and divergent proper naming, most of which will never gain any stronger traction or wider adherence in the world but will rather wither away or fall to the wayside, whereas others will be vested with greater degrees of staying power. Far from amounting to some form of spontaneous stabs at order out of the blue, propositions for regionalization constitute responses to concrete problems or challenges for some actor or group of actors that the current established spatial arrangements are unable to tackle or amend. Even though generating emergent effects, such propositions are also by necessity always derivative of the multilayered social/political/economic/technical/cultural configurations of the particular time-space conjunctures at which they are articulated (and then, given shifts in the configurations, iteratively re-articulated) - and hence not reducible to any single logic such as 'state formation' or 'capital accumulation'.[FOOTNOTE 2] Taking form in a world always already ongoing, and to its nature being a relational entity, the nascent emergence of a regional Leviathan as encompassed by a proposition for regionalization thus always entails a coding or overcoding operation of capture (i.e. demonstrating that the region already is), connection (i.e. claiming that the region can/must be) and organization (i.e. making the region become); all three aspects most often in one way or the other sliding or vowen into each other in operations of extraction and binding-together of some features and elements of a complex reality that appear to connect or could be made to connect - while ignoring or actively countering other existing or potential connections (cf. Deleuze \& Guattari, 1987). These operations of attempted capture, connection and organization can be performed through intentional or strategic discursive interventions - but also in many other ways. For we mustn't forget all the 'silent' articulations of a region that constantly circulate and enact the region without much fanfare or fuss, that is - not in the form of passionate pledges of allegiance or visionary statements but rather through less conspicuous media that generate more implicit and/or taken-for-granted assumptions of territorial 'belonging-togetherness' through producing/reproducing spatialities by way of 'hardwiring' into maps, software, transport infrastructure, legal code, financial support programmes, etc. - all of which contribute to more or less actively 'doing' (enacting/performing) a certain spatiality in a particular way, i.e. a particular version of the region (for a similar perspective concerning 'the city', see e.g. Latour \& Hermant, 2006).

\section{Propositions for regionalization that travel and stick}

Since the region as an actor (i.e. the region 'as a region') at an early non-institutionalized stage primarily holds together in the form of discursive statements and is not itself endowed with the capacity to speak 
for itself and make itself heard, others' reproduction and multiplication of those statements becomes crucial for its existence. One could almost say that for a specific regionalization to "stick" it also has to "travel", through being carried by other actors (see also Albrechts, 2010; Barnes, 2002; Healey, 2007; Latour, 2005b). Ironically, considering the everyday use of the terms (where the one signifies mobility and the other inertia), the more a certain proposition of a region can travel - that is, be picked up and carried around and placed in new contexts through the adaptations and translations of and by new actors - the better are its odds for sticking around (Latour 1999, 2005b). 'Sticking around' would in this context refer to gaining staying power through becoming objectivized and 'real' in the banal, common sense use of the term - as the opposite of 'fictitious' (See Latour 1987, 1999, 2005b). In a different wording: a region, as a proposition, must be both durable and mobile (Law, 1992), and rely on other actors to carry it and to extend its reach through immaterial or material practices, because - as related above - a specific composition of a region, viewed as a proposition for regionalization, can either be picked up or let down (cf. Latour, 1987:29). Propositions for regionalization that fail to be widely communicated, that fail to travel, will most probably also fail to stick and become institutionalized. Of course, propositions for regionalization in the form of discursive statements cannot travel in some form of mysterious extra-material symbolic dimension. All travel takes place through very concrete material media which often include human bodies that can communicate directly with other humans in personto-person interaction, but almost always also in the form of other types of material devices that more or less faithfully can transport and communicate discursive statements across geographic distances - e.g. in the form of documents, maps and computer code - which again function as relays in the formation of emerging regional networks always consisting of both human and non-human components (see Czarniawska \& Sévon, 2005:8).

In the process of travelling through being 'passed on' by other actors, which has been called both translational (Latour, 1987) and citational (Gregson \& Rose, 2000), a certain degree of fungibility and mutability appears to work to the gain of the proposition, making it more translatable into the schemes and interests of others and making it easier to adjust to the particularities of new actors and contexts while still holding some degree of agency and continuity (see also Lagendijk \& Cornford, 2000; Law \& $\mathrm{Mol}, 2001)$. Thus, as a proposition for regionalization is passed on between actors, we can expect that displacements, translations and negotiations back and forth of what the region really is and should be will occur as different actors translate, displace and modify the proposition in their own way and according to their perspectives and perceived interests at a specific given point in time (Paasi, 2012; cf. Latour 1987, 1999). Seeing that various propositions for regionalization relating to the same geographic 
area may be in circulation at any given time, and that these propositions are likely to mutate as they are passed along, this means that we often cannot talk of the region in the singular, but must rather refer to it in the multiple - as simultaneously existing, alternative propositions for regionalization that are sometimes (but only sometimes) mutually exclusive (see further Law 2000, 2007; Mol, 1999). In the quest for coherence that practically amounts to an 'ontological-political' (Law, 2009; Mol, 1999) jostle between different versions of the proposition for regionalization - the more allies a certain version of the region will be able to muster, the more influential and dominant it will become, leading to increasing costs (both financially and otherwise) for those who wish to dispute or challenge this particular proposed version (cf. Latour, 1987).

Stabilizing the regional Leviathan: institutionalization through delegation into durable materials

As a certain version of a proposition for regionalization gains momentum and weight, and increasing degrees of closure are achieved around a singular version of the region, the specific proposition may within time become extremely difficult and costly to attempt to challenge or reverse (Paasi, 2001; Painter, 2008; see also Latour, 2004). In this context, partly inspired by Paasi (1986) but more directly building on Latour $(2004: 109,243)$, the term institutionalization may be used to refer to the processes through which propositions for regionalization are increasingly stabilized through delegation into more durable sociomaterial forms than discourse - for instance organizations, transport links, legal statues, etc (Latour, 1999:187; Law, 2001). Therefore, following Law, we can say that propositions for regionalization and the way they are composed really do matter, in both meanings of the word (Law, 2004). To give a very brief example from Northern Europe, the bridge across the $\varnothing$ resund sound, linking up Copenhagen to Malmö, is a very material performance of the proposed Øresund-region, and it is also performative in itself in that it facilitates practices, such as commuting, that increasingly will strengthen the staying power of the proposed regionalization.

Of course, also non-human articulations of the region, such as bridges, can with considerable effort be challenged and disbanded or destroyed, but once a region becomes increasingly institutionalized it may require a much costlier and more sustained effort as it is often politically, economically and practically more challenging to reconstruct or tear apart motorways, fibre-optic cable networks or town settlement patterns than just going up against a region that so far only consists of vague speech and some inscriptions upon paper (even though very vague and thereby fluid spatialities can be highly challenging to eliminate once and for all, see e.g. Metzger \& Schmitt, 2012 concerning the British 'home countries'). This can be seen as the background to Latour's (1999:210) claim that non-human allies to a proposition 
often are more reliable than human allies, as they tend to "remain in place" (Latour, 2005b:199), and facilitate higher degrees of irreversibility or 'stickiness', thus in many ways being more durable (Law, 1992). Through their often dumb, unintentional and unreflective agency non-humans often facilitate processes without questioning them, which humans sometimes tend to do - making humans into more fickle and unreliable allies. Following this line of reasoning, it can be argued that propositions for regionalization that succeed in being delegated into non-human agency generally tend to become more durable, and thereby also more non-negotiable in their existence than the propositions for regionalization that fail to do so; and where those that fail to do so as a result most often will come to be sorted under the common perception of having been a 'mere social construction' (cf. Paasi 2001, who distinguishes between "regions on paper" and "regions as social practice").

Here we might also find a tentative explanation as to why some regions seem more 'natural' to us than others: they are simply institutionalized to a higher degree and have often stayed in place for a very long time - and are therefore also made to travel on a daily basis, quite unproblematically. In the terminology of Callon \& Latour (1981:285) they have become "black boxes": "those things whose contents have become a matter of indifference". The generation of such black boxed-relations which come to constitute undisputed and seemingly self-evident taken-for-granted realities are according to Callon \& Latour the foundation of any durable and successful Leviathan for " $[t]$ he more elements one can place in black boxes - modes of thought, habits, forces and objects - the broader the construction one can raise". When successfully performed, black-boxed relations, for instance a specific proposition for regionalization, thus come to be reproduced unreflexively and unproblematically as a collateral reality (Law, 2009), without much of a fuss or conscious reflection. But those regions which we apprehend as 'artificial', on the other hand, are usually not so well institutionalized yet, and therefore still only travel with a large amount of effort involved, not having achieved any considerable degree of staying power yet.

From such a perspective there is thus no ontological or perhaps even methodological distinction to be made between 'old' and 'new' regions. Rather, 'old' regions seem natural to us because they are the 'success stories' that have through various measures managed to stick on and become black-boxed taken-for-granted realities since long, and therefore are seen as completely natural and proper. Nevertheless, the existence of such 'still living' and naturalized propositions for regionalization must not make us lose sight of the overflowing graveyard of all the other, failed, 'old' propositions for regionalization - those that never caught on or fell to the wayside at one point or the other. So the 
difference between 'old' and 'new' regions must not be mistaken as ontological, but is rather perhaps best conceptualized as an evolutionary difference - where 'new' regions simply have not yet been along round enough to pick up the status of unreflected, taken-for-granted collateral reality.

To conclude, this means that the 'objectivity', i.e. the stability and integrity of a region-as-object, does not hinge upon it fitting with some underlying reality, but rather with how well-established and institutionalized it has become. Such a perspective may help shift the discussion on regionality from dead-end philosophical debates over whether regions are 'real' or 'constructed', to instead begin to empirically consider how multiple and sometimes competing propositions for regionalization may come to be successfully singularized and institutionalized - 'black-boxed' - through delegation into stabilized sociomaterial forms (see also Paasi 2010). Still, in their paper on the Leviathan, Callon \& Latour (1981:285) argue that "black boxes never remain fully closed or properly fastened... we are all constantly struggling for closing leaky black boxes", a point which we will find reason to return to towards the end of this paper.

\section{Conceptualizing regions-in-becoming as publics-in-stabilization}

Paasi (1986) has suggested an analytical model of four non-sequential stages for conceptualizing the formation and institutionalization of regions. Even though the model presented by Paasi successfully draws attention to the historical contingency and conditionality of processes of regionalization, it can be argued that his model primarily focuses attention upon important objects of contestation in processes of regionalization - such as the territorial shaping, symbolic shaping and institutional shaping of a region-in- becoming. These outcomes and objects of contestation are of course important components of regionalization processes, but Paasi's model does not supply any particularly concrete conceptual tools for empirical investigations of the dynamics between actors in the described processes towards regionalization. If we instead wish to focus upon the unfolding of the processes through which these outcomes are achieved with the purpose of developing a further understanding of the mechanics of such processes, we might instead let ourselves be influenced by a different literature emerging in the cross-currents between pragmatist political philosophy and ANT. Drawing primarily upon the work of Marres (2005a, 2005b), it is thus suggested that processes of regionalization, when successful, might be conceptualized as the development of loosely knit regional publics into emergent regional stakeholder communities, which may eventually also become stabilized in more durable and costly-to-reverse forms and materials - finally achieving a naturalized status as a taken-for-granted regional territorial entity. 
The proposed model sketches three consecutive phases through which such processes often appear to progress:

1) The emergence of a regional public through intertwined processes of [a] articulations of territorially framed common concerns and [b] regional stakeholder subjectification

2) The stabilization of a regional public through [a] the formation of a regional stakeholder community and $[\mathrm{b}]$ the singularization of the proposition for regionalization

3) The institutionalization of a region through [a] the formation of recognized regional spokespersons and [b] the delegation of the proposition to more durable sociomaterial forms

According to this proposed model each sketched step of the regionalization process entails a "double articulation" (moments [a] and [b]), where the content and form of the proposed region become concomitantly produced through co-constitutive and mutually reinforcing mechanisms and developments (cf. Deleuze \& Guattari, 1987). It is in no way meant to be read as a teleological model. Not every proposition for regionalization will go through these stages, not even those that appear to have begun to embark upon a trajectory towards institutionalization. Thus perceived, regionalization processes can, and often are, interrupted or completely arrested at any given stage of development. Further, it is often impossible, other than post-hoc, to conclude which processes will pick up momentum and which will be thwarted or derail - even though there of course are more or less likely candidates at any given point in time. The above sketched model, which will also be further elucidated below, is thus not intended to function as any form of predicative tool - but rather as a heuristic device to enable researchers of regionalization to grasp some of the dynamics and mechanics of these processes that may otherwise be difficult to get a handle on. [FOOTNOTE 3]

The emergence of a regional public

In No issue, No public Marres (2005a) explores processes of issue formation and how the formation of contentious public issues engender the emergence of publics that raise demands towards the settlements of such issues. According to Marres' argument the formation of a public is always irrevocably bound up with the emergence of a specific issue or problem that the actors constituting the public find themselves entangled in, and hence seeking redress for. Marres argues that such publics arise when existing institutional frameworks prove unable or ineffective at settling the issue in question, thus generating a public controversy of some sort or form in which actors become caught up - in the process forming a public. Marres thus uses the concept of 'the public' to come to grasp with the 
heterogeneous and potentially geographically dispersed assemblages of actors that become attached or caught up with a specific public issue or problem. In her discussion of the concept Marres notes that the "prototypical" public is often thought of as consisting only of laypeople (Marres, 2005a: 99), but may according to her definition nevertheless be used as a designator for all the clusterings of actors carrying conflicting positions, interests and views that become articulated in relation to a specific issue, thus forming the nexus of an imbroglio. Following this line of reasoning, it can thus be argued that the emergence of a regional public is a process where issues are put on the table, and these issues are being articulated either as demanding solution through regionalization. Further, conceptualized along these lines, the regional public that may come to assemble around such issues need not be limited to only laypersons living in the proposed region, as defined in Euclidean space, and isn't even limited to 'individuals' - but may rather consist of all sorts of geographically dispersed networks and organizations, including (but not limited to) business promotion networks, government agencies and cultural associations, who become topologically rather than topographically attached or caught up in a regionalization process generated by the issue - either by way of their own deliberate actions or commitments, or as the consequence of the purposeful or unwitting activity of others.

When a regional public begins to emerge as the result of the regional territorial framing of common concerns, we are at the same time witnessing a process through which territorial, regional stakeholder subjectivities are coming to be established thus constituting a regional "community of concern" (Marres, 2005a:61), or "community of fate" (Braithwaite, 2008). This stage of the process enacts the binding together of actors that are beginning to become mutually implicated in the proposition for regionalization but who have previously been attached to different logics of operation. What is going on in this stage of the process is the establishment of how concerns are (or rather can be) shared and how interests (can) converge. The establishment of regional territorial logics through the fostering of stakeholder subjectivities thus implies what planning scholar Patsy Healey describes as a "bringing together on a territorial basis relations which have been separated off in many cases into institutionally distinct functional sectors... in order to identify precisely where the points of strategic common interest lie, and to build on that institutional capability to address them" (Healey, 2006:77). As Healey puts it, this is the moment when actors begin to "think about the complex interrelations of what happens in a place and where their concerns fit with those of other[s]" (Healey, 1998:1539). So it is not only a process of sharing interests and concerns, but also about how these interests and concerns are framed and contextualized in territorial terms - as part of a wider taking-in-regard of the well-being of a specific area, about placing concerns and interests within a specific regional territorial frame. 
At this stage actors pursuing discursive methods and devices to proactively lobby for the regional territorial framing of the raised issues and concerns might be seen as of crucial importance, as it is at this stage of the process that actors become woven together through the establishment of a climate that generates a sense of 'your concerns are mine, but my concerns are also yours'. To achieve this, there must be agents for regionalization setting up forums that enable a "fusion of interests" (Latour, 1983:150) and where "mobilizing talk" is being performed through the "lassoing" or "envelopment" (Latour, 2003) of actors in a common territorial framing by arguing that their particular concerns and interests can only be tackled through the adherence to an integrative, territorial logic that establishes a specific spatially defined area as a shared co-responsibility and concern of the actors. In this context, 'stakeholderness', the subject position through which an actor concerns itself to 'have a stake' in and therefore committed to the fate of a specific entity, is never an actor-property that is ontologically given. Rather, as Marres (2005a:62) succinctly argues: "the state of being affected by an issue should not be understood as given, but rather as the achievement of a process of "learning to be affected'". In the same vein, Featherstone (2007:298) notes that we should not view solidarities as fixed interests formed around a static object, but rather see that interests and solidarities "become constituted through ongoing, contested, multiple practices that are engaged in actively shaping the world". [FOOTNOTE 4]

\section{The stabilization of a regional public}

As issues that cannot be satisfactorily settled within existing institutional arrangements are framed in territorial terms and regional stakeholder subjectivities begin to emerge, we might see the formation of a loosely knit 'community for the interest of the region', or regional stakeholder community which carries forth a proposition for regionalization. The composition of this community will to a large degree determine the 'essence' of the proposition for regionalization, the communicated idea of what the region is (and, very importantly, by defining what the region is - also sets a trajectory for what it reasonably can be expected to become). 'Essence' must here of course be understood in fully relational terms, as an attributed 'virtual' and thus contestable property: the emerging results of operations of capture, connection and organization according to a principle of 'belonging-together-in-space' (see Latour, 2004:241 on the attribution and stabilization of essences, and also the discussion in Paasi, 2010). Thus, one could claim that when a proposition for regionalization is being articulated, the stakeholders carrying the regionalization are being articulated (or articulate themselves) with it (cf. Gregson \& Rose, 2000:442). Thus, the perceived or attributed essence of a regionalization is never ontologically given. Regions and stakeholder must be seen as co-constituted in the process of regionalization as various 
actors become subjectified as stakeholders and thus attach themselves to the proposition for regionalization. Context and content become mutually constitutive (Callon \& Law, 1995). Regional(ized) stakeholders begin to act as mediators for the proposition for regionalization, carrying it further, arguing for it and attaching their own concerns to it -and at the same time - attaching themselves to the regionin-becoming.

Here, it is also important to remember that through the formulation of issues and of the 'stakes' of actors in these issues, and through framing these stakes territorially by tying them to a certain proposition for regionalization, the proposition for regionalization is modified, or 'translated'. But so are the actors being tied to the proposition as allies. So, as previously stated, here we are witnessing the formation of an emerging region and an emerging community of stakeholder subjectivities that are carrying each other that are mutually constitutive. We can also see that when an actor is being translated/translating itself into an ally for a proposed regionalization, the proposed regionalization gains in weight and momentum, but at the same time the proposition for regionalization is modified as new concerns and causes will be added to the proposition for regionalization, modifying its essence. The cause or concern of the actor attaching itself to the region also gains new momentum, as it is then no longer just a cause or concern of a lone partisan actor, but now rather has been transformed into a cause or concern of the (proposed) whole region.

As an increasing number of actors are attached to a successful proposition for regionalization, the more momentum it gains and the region begins to 'stick' through 'travelling'. The ensuing formation of a regional stakeholder community who recognize each other as mutually implicated in a series of entangled and spatially framed co-affective issues, will often lead to the establishment of a discourse of caring and planning for the future of the territorial entity imagined as best suited to provide the means for practically addressing the identified issues. The articulation of such a discourse of mutual worry, caring and planning - signifying the emergence of a regional stakeholder community - can therefore be conceptualized as an important moment in the establishment of the preconditions for aligning a loosely formed regional public into a more stabilized proposition for regionalization.

As actors start to become tied together and attached to a certain proposed regionalization, the proposition for regionalization will also become increasingly singularized as commensurabilities are generated in the process of establishing what concerns and interests can be shared between actors as concerns and interests of the region. It is in this process of singularization of the proposition for regionalization that values are made to meet, and new values are generated (Corvellec, 2001:202). In a 
way then, this stage of the regionalization process actually entails the negotiation of the essence of the region. During the course of these negotiations, incommensurates - the issues which actors really appear to be unable to share - will be shifted out of the process; and with that some actors that are strongly attached to these issues might fall off as they are unable to agree upon what perhaps could be called the emerging 'terms of regionalization', that is, the emerging attributed essence of the proposed region. At the same time it will also begin to appear as all the more inevitable and undisputable to actors that the region is an emerging reality that must be taken in regard, which means that new actors will begin to be drawn into the process.

\section{Institutionalization of the region}

It is in this next stage of the process that those who see some value in distinguishing 'real regions' from 'regions on paper' often put a great emphasis. If a regionalization process reaches this stage of development, the region has in some ways already become very much 'real' through the emergence of a community of stakeholders who are attached and committed to the proposed regionalization. Still, the vast majority of propositions for regionalization never stabilize beyond the state of a non-coherent, vague and fragmented regional public or loose stakeholder community, while a small number of propositions might succeed in becoming stabilized to such an advanced degree that they within time become widely taken-for-granted and natural(ized) regions. To be able to do so, the proposition for regionalization and the essence and interests of the region must be further stabilized through the endowment of an actor with a widely recognized responsibility to legitimately act as a designated common spokesperson, with the right to speak on behalf of the interests of the proposed regionalization.

The actor(s) who take upon themselves or are vested with the capacity to act as the voice of the region, to speak of and for the region can be seen as attempting to assume a status as a clearing house of regionality and takes upon itself the right to formulate the interests of the region and the power to define what belongs to the region and not (Latour, 2005b:31), hence both positioning itself as the legimitate embodiement of the voice of the region, and at the same time articulating the essence of a particular proposition for regionalization (cf. Cooren, 2010; Latour, 2004). Of course, as a proposition, the version of the region being touted by a specific, maybe self-elected, regional spokesperson can always be challenged; and often we will see many different actors scrambling to make a claim to being the legitimate spokesperson of a region, all with their own slightly (or majorly) different propositions for regionalization (cf. Cooren, 2010:168). But as already related above, if a number of actors begin to align 
around a certain definition of the region and its interests, and directly or indirectly grant the spokesperson authority for that version of the region to a certain actor, we can sometimes see the development of a type of snowballing logic, whereby an increasing array of actors more or less willingly or coercively become locked-down into the configuring network being woven around a specific prospective regional spokesperson authority. As the spokesperson succeeds in mustering an increasing number of such allies, it will to increasing degrees come to resemble the mouthpiece of a regional 'Leviathan' as other actors accept the authority of the spokesperson to speak for their essence and interest in exchange for the envisioned benefits or necessity of 'buying-in' into the emerging terms of regionalization, further also leading to increasing difficulties for those who attempt to dispute or challenge this particular proposition of the region.

It is also at this stage that not only the mouthpiece of the Leviathan becomes clearly formed but also its body, through the delegation of the proposition towards regionalization into more durable and costlyto-reverse materials - thus further stabilizing it. This may for instance occur through the formalization of organizations and political-administrative units or through the construction of physical infrastructure or other durable land-use developments that materially locks down or 'hard-wires' the recurrent and stable enactment of the proposition for regionalization into the fabric of various broad aspects of everyday life, be it through financial distribution mechanisms, land-use planning or any other material(izing) mechanism that will silently and relentlessly constantly reproduce the specific proposition for regionalization without any need for fanfares or fuss, making the region 'happen' by bearing down upon or formatting worldly events on a recurring and regular basis. The agency of the region as an actor or 'actant' in its own right already begins to appear in the early stages of the regionalization process through the emergence of regional stakeholder subjectivities that generate territorial attachments and there-through come to guide action and decisions; but it is primarily through this materialization in durable materials that the region becomes not only an actor made to act by others- but also extensively comes to act back upon or even steer others' actions as an actor or 'actant' in its own right.

\section{Studying three contemporary processes of regionalization as publics-in-stabilization}

In the previous sections of the paper it has been claimed that studying regions-in-becoming as publicsin-stabilization might help researchers illuminate the contingency of stabilized regions, and further that such a perspective might give us new purchase on how regions form, evolve and (sometimes) stabilize. In this section of the paper, the conceptual model sketched above will therefore be put to work in the 
study of three contemporary processes towards regionalization in Northern Europe, with the purpose of learning what aspects of these processes the model will help us highlight, and what challenges that arise when the model is applied to concrete empirical material. The three cases that will be granted a closer examination in the paper are the Mälardalen region - the wider sub-national regionalization of the greater Stockholm area, the Øresund region - the cross-border, transnational regionalization between Sweden and Denmark, and finally the Baltic Sea Region - the 'macroregional' regionalization of the Baltic Sea area. The chosen cases purposely have radically diverging geographic scopes and reaches, and all to various degrees cross administrative borders such as national borders, to illustrate that processes of regionalization are trans-scalar occurrences that, more than anything, bend existing scalar structures and institute new scalar entities. Further, the examined cases all have very divergent institutional backing and structures - which hopefully might show whether the model for conceptualizing processes towards regionalization outlined above can be relevant in diverse administrative-judicial environments and contexts, and if it may serve to highlight oft-shared aspects of processes towards regionalization notwithstanding important contextual divergences.

The regionalization of Mälardalsregionen, or Stockholm-Mälarregionen as it is also known, has primarily been documented by Westholm et al (2008). Mälardalen as a region is not defined by any formal territorial boundaries, and no formal political-administrative institution that corresponds to it exists. Nevertheless, for many political and administrative actors in Sweden on all levels of government the region of Mälardalen is today considered to be a very real and active entity, endowed with both powers of agency and rightful claims (Stenlås, 2008:17). But this perceived regional unity is a relatively new phenomenon. The area today generally considered to compose the Mälardalen region has historically rather been marred by considerable political-adminstrative strife and animosity along a number of fault lines, including - but not limited to - conflicts between the City of Stockholm and surrounding municipalities, between the County of Stockholm and surrounding counties, between the northern supposedly wealthier parts of the greater Stockholm area and the more populous south, and between the Stockholm County to the east (containing the capital city), and the historically powerful industrial towns further west along the shores of Lake Mälaren.

The case of the emergence of the transnational $\varnothing$ resundsregion, across the $\varnothing$ resund strait between the cities of Malmö in Sweden and Copenhagen in Denmark, has been well documented, for instance in the volumes edited by Lyck \& Berg (1997) and Berg et al (2000) and by Jensen \& Richardson (2004).

[FOOTNOTE 5] The Øresund region is today considered one of the real success-stories of European 
cross-border regionalizations, with a grand centerpiece in the imposing and impressive $\emptyset$ resund Bridge that physically ties together the city of Malmö in Sweden with the capital city of Denmark Copenhagen; and on a wider scale, the Scandinavian Peninsula with the rest of continental Europe. Still Berg (2001) notes that the idea of a regionalization tying together Sweden's southernmost area, Scania - where Malmö is located, with the Danish island of Zealand - where Copenhagen is located, was long considered a complete pipe dream, a "re-li-gion" more than a "region" (Berg 2001:175). Still, today, very few will question the reality of the Øresund region. It has become almost ubiquitous due to the high degree of cross-border commuting, transnational settlement patterns and co-operations on all levels that exist today across the narrow strait.

With regards to the transnational Baltic Sea Region, the process towards regionalization has previously been explored by, among others, Lehti (2009) and Metzger \& Schmitt (2012). Since the fall of the Iron Curtain, there have existed numerous initiatives for a proposed regionalization of the wider transnational Baltic Sea area, most often envisaged as including countries such as Sweden, Finland, Denmark, the Baltic Republics (Estonian, Latvia, Lithuania), parts of Poland, parts of Germany, parts of Russia - and sometimes also countries such as Norway and Byelorussia. But already towards the end of the 1990s, as the initial scramble for regionalization of the Baltic Sea appeared to mellow out, it seemed as if the proposed regionalization of the Baltic Sea Region (BSR) was already a lost cause as a futureregion (Lehti, 2009:18). Nevertheless, with the launch of the European Union Strategy for the Baltic Sea Region (EUSBSR) in 2009, the regionalization of the BSR appears to be one of the most active and institutionally backed conscious region-building projects in contemporary Europe.

\section{[INSERT TABLE 1 HERE]}

Table 1 has been organized according to the proposed conceptual model consisting of three interconnected phases. These phases include the emergence phase, when a regional public begins to take form through the articulation of territorially framed shared concerns, which occurs in parallel with the formation of regional stakeholder subjectivities that bind together actors who have previously not seen themselves as belonging together or sharing concerns or a common fate. In the stabilization phase, a regional stakeholder community begins to take form and become organized, although often in rather loose and informal forms. Relatedly, a singularization of the proposition for regionalization through the emergence of a more unified or singularized discourse outlining the attributed essence and interests of 
the region can often also be witnessed in this phase. Finally, in the phase which entails the institutionalization of the region we will most often see widely recognized spokesperson authority concerning the articulation of the essence and interests of the region being bestowed upon some particular organization or agency. This spokesperson formation can also be seen both as part of further contributing to a further delegation of the proposition for regionalization into more costly and difficultto-reverse forms of stabilized sociomaterial relations such as infrastructure development, and these further often become the publicly recognized 'concrete outcomes' of regionalization processes that are used as examples of a particular region being 'real'.

Emergence phase: territorially framed concerns \& regional stakeholder subjectification

In all the three examined empirical cases the articulation of new, territorially framed concerns played a central role in the early stages of the formation of a regional public. Sometimes these concerns were previously not articulated but were now put on the table as specifically regional concerns, in other instances they were previously debated concerns that were now rearticulated in a regional territorial framing, or as the basis for a supposedly needed collective regional mobilization. It can further be noticed that in all three cases, new collective subject positions are being invoked in the articulation of these concerns, and these collective subjectivities are often selectively contrasted against and/or linked up to other existing or potential subject positions such as local, national or European identities.

In Mälardalen, national county administration boards (Länsstyrelser) and municipalities (Kommuner) formed taskforces in the late 1980s to begin to probe what were seen as issues of common concern that needed to be dealt with collectively in the wider region - for instance the water management of lake Mälaren, located in the centre of the region, but also common interests in transport infrastructure development such as the planned extension and refurbishing of the national railway network and the supposed effects of this upon the counties and municipalities around lake Mälaren. Central to this process was the emergence of the idea that there existed common interests and concerns that were specific to the Mälardalen counties and municipalities in opposition to the interests of other perceived regionalizations, such as the northern parts of the country or the urban areas around Gothenburg and Malmö. Also, the articulation of common concerns were put into direct contrast against the previously existing, ingrained local identities of different parts of the Mälardalen area, which were increasingly 
framed as irrelevant and even dangerous due to the resulting incapacity to act collectively on pressing regional matters.

Around $\varnothing$ resund vague ideas existed already in the late nineteenth century, especially on the Swedish side, to connect the Swedish southernmost region of Scania to continental Europe by ways of an overland connection. But the idea of the economic development potential of a shared Swedish-Danish cross-border regionalization only picked up real momentum in the 1970s, and then primarily on the Swedish side among local politicians and academics in Scania but without any wider initial support from the Danish neighbors or any national government. In the 1980s the idea of a shared regional fate between the Swedish region of Scania and the Danish region of Zealand was infused with new energy, among other things due to the articulation of these concerns also within the frame of a discourse of europeanization, and mounting suggestions that national governments needed to tap into the potential of a common Swedish-Danish Øresund region in competition with other strong European cross-border regionalizations. So the emerging collective subject for action that emerged was articulated on the one hand against existing national identities that supposedly clouded the cross-border regional interests and potentials, and on the other hand in relation to other regions in Europe that would be slipping too far ahead of the $\emptyset$ resund region in terms of economic development if efforts to further develop crossborder regionalization were to be postponed.

As for the Baltic Sea Region, during the last awkward years of Soviet rule on the eastern shores of the Baltic sea in the late 1980s, activists both within academia and politics in countries such as Germany and Sweden had begun to articulate common cultural heritages and calling for a revival of a Baltic Sea collectivity based on a shared common heritage and mutual contemporary concerns, such as the potential for becoming a core economic region within a revamped European community. The collective subjectivity being called upon in these discourses was posited primarily against the perceived unnaturalness of the East-West divide of the region imposed by the cold war, and further drew upon the idea of a shared community of fate for the areas around the Baltic Sea, as against more narrow forms of national identification.

Stabilization phase: stakeholder community \& singularization dynamic

In this moment in the regionalization process we can in all three cases observe the emergence of nascent, more or less formalized stakeholder communities in the form of network structures or more or less informal and non-committing organizations. These function as forums for discussions around issues 
of common concern and to various degrees also serve to generate shared, collective self-knowledge as the basis for collective action and/or generating public debate and publicity concerning common concerns. This both occurs through person-to-person contact in e.g. meetings or conferences, but also through other devices and material media - a veritable flurry of maps, plans, strategies and brochures. Further, in this stage of the regionalization process, it is also possible to observe some form of a singularization dynamic and slowly emerging partial consensuses regarding the essence and interests of the proposed regionalizations, with the BSR constituting somewhat of an exception in this case.

In the Mälardalen region, the 1990s saw the formation of a number of organizations and networks speaking for, and about, a proposed/supposed Mälardalen region. This included both 'Mälardalsgruppen' (later becoming 'Mälardalsrådet', see further below) and more informal networks, such as the regular cooperation that emerged in the later part of the 1990s between the various national county administration boards for the counties surrounding Lake Mälaren, together with the regionalized national infrastructure-providing agencies such as the national road authority. With regards to the singularization of the proposition for regionalization this development was advanced for instance through the production of common strategic document and reports, outlining collective regional plans and goals. Especially the local process underpinning the publication of the OECD Territorial Review of Stockholm-Mälar Region (OECD, 2006) has been highlighted as a key moment in the generation of a shared, common idea of the essence and interests of the Mälardalen region (cf. Stenlås 2008).

In the Øresund area, the 1990s saw a veritable boom in transnational regional organizations and networks, tying together both public and private actors and NGOs in sometimes unexpected ways. One observer has noted that over 500 organizations were active in the various projects, programs, events and activities that could be ascribed to the regionalization process in the area from the mid 1980s and up until the beginning of 2000 (Berg 2001:178). From 1991 up to 2000, over 150 strategy documents were produced regarding the emerging region, including vision statements and strategic plans - in addition to a number of regional policy documents sponsored by various national and regional authorities in both countries. Consolidation of plans and shared ideas concerning the essence and interests of the region only emerged slowly from this plethora of documents, and patchily at that.

In the Baltic Sea regionalization process, the 1990s saw the initiation of numerous initiatives, programs and organizations aiming at furthering the regionalization of the area surrounding the Baltic Sea. Initiatives often came from the western shores of the Baltic as part of the enthusiasm to include the recently independent Baltic republics into a new European transnational community. These included 
various EU INTERREG programs, the Council of Baltic Sea States, the Nordic Council of Ministers, the Baltic Sea States Sub-Regional Cooperation, Union of Baltic Cities, Baltic 21, the Helsinki Commission and the NB8-group - to mention but a few of the organizations and constellations that are sometimes referred to as the 'alphabet soup of the BSR' due to the many acronyms of organizations with overlapping agendas and activities in the region. Soon enough, though, it turned out that there existed widespread dissensus regarding the desirability of a Baltic Sea regionalization. While the western countries of the Baltic Sea area found themselves within an emerging process of neo-regionalization, the former communist republics were still focusing on consolidating borders and national boundaries, and were busy crafting a national - and to some extent 'western' and European identity, wherein a label of "Balticness" was not seen as very befitting. This led to a mellowing out of the first scramble for regionalization of the Baltic Sea towards the end of the 1990s. But even if the BSR regionalization efforts of the 1990s failed to really travel widely, they still left a living heritage of a wide and disparate organizational patchwork of actors that saw themselves as part of a wider BSR context, even though all articulating the essence and interests of the region in sometimes very diverging terms.

Institutionalization phase: spokesperson formation \& recognized outcomes

In the examined empirical cases we can in all three instances distinguish a third stage of regionalization following upon the previous two in which the region - from having been a type of project or proposed entity - begins to become all the more taken-for-granted and considered a natural reference point of established reality. In this phase we can in all three cases observe the emergence of recognized regional spokespersons, endowed with more or less privileged rights of speaking in the name of the region. Also, in this phase regional concerns have become so widely accepted that they now also appear to guide or at least influence difficult- or costly-to-reverse patterns of development, such as major infrastructure projects or land-use developments, which then also come to be recognized as not only concrete outcomes of regionalization processes, but also as signs of the solid reality-status of the regions as something 'existing out there' which comes to function as a seemingly self-given reference point in reality.

In Mälardalen Mälardalsrådet, which was founded in 1993 and with a membership of 56 municipalities and six counties, has increasingly come to be treated as a legitimate spokesperson for the wider region. It is a pronounced network organization with only a handful of employees. The member delegates meet up once a year at the Mälartinget assembly. The organization also has a civil servant coordination group and four standing committees on culture, business development and R\&D, infrastructure and planning, 
and environmental issues. The organization participates in political processes as a joint representation for the member organizations, especially in national infrastructure processes. Still, formally, it is an interest organization with no formal administrative or political status. It is politically non-partisan and has no (formally) delegated powers of representation. With regards to recognized outcomes, the articulated common interests of the Mälardalen region have, among other things, also had a pronounced impact upon the strategic development transport infrastructure in Sweden, among them the so-called 'Stockholm agreement' on major infrastructure development in the Stockholm area. Another important recognized outcome that also functions to strengthen the regional linkages in Mälardalen, and there-through generated a daily 'enactment of the region, is the public transportation co-operation within the companies MÄLAB and TiM that are co-owned by the individual Mälardalen counties' public transportation agencies. These organizations have with increasing intensity contributed to a coordination of the public transport systems of the Mälardalen counties, i.e. by instigating and financing new cross-county rail commuting , offering subsidized monthly commuter cards for crosscounty commuting and also through organizing a partial merging and harmonization of ticketing and timetable systems across the counties, all of which has greatly contributed to simplifying daily crosscounty commuting across the wider Mälardalen region.

Today the so called Øresund committee is generally regarded as the legitimate spokesperson of the $\varnothing$ resund region, an organization with a structure and modus operandi very similar to that of Mälardalsrådet, albeit with a somewhat higher degree of resources and activity. Some of the most influential constellations during the early stages of the regionalization process were never transposed into any durable forms and rather withered away or fell apart. The most widely recognized outcomes of the $\varnothing$ resund regionalization is of course the towering bridge-tunnel transport link across $\varnothing$ resund, creating a land transport connection between Sweden and Denmark - but also the increasing patterns of cross-border commuting and settlement, partially resulting from the construction of the bridge, are today widely drawn upon as evidence of the 'objective' existence of an integrated cross-border region in $\varnothing$ resund.

After a long period of apparent stagnation in the process towards BSR regionalization, efforts gained new momentum towards the end of the 2000s with the launch of the European Union Strategy for the Baltic Sea Region (EUSBSR), which was officially ratified and approved by the EU member states in 2009. With the adoption of the strategy and the related governance structure, the European Commission through DG Regio - in practicality becomes placed (or rather places itself) in the position of acting as a 
"metagovernor" with the capacity to outline the essential characteristics and common interests of the region (Metzger \& Schmitt, 2012). With regard to concrete, recognized outcomes of this more formalized institutionalization of the essence and interests of the BSR, it still remains to be seen what this will/may entail as the regionalization as of yet does not appear to be fully naturalized or taken-forgranted in any wider circles.

Discussion of the model in the light of the empirical findings

The attempted conceptualization of three different contemporary regionalization processes as publicsin-stabilization evinces that there are both important similarities and differences between the cases at hand, both lending support to - and sometimes also putting into question - the relevance and applicability of the conceptual model being proposed in the paper. To begin with, in all of the three examined cases, roughly sequential processes can be traced entailing the emergence of regional publics, their stabilization and their institutionalization as recognized regions - even if the temporal hiatuses and overlaps in these processes vary greatly between the cases. Further, the mechanisms of emergence and stabilization sketched to be entailed in these processes also appear to have been at work in all of the three examined cases including the regional territorial framing of concerns, the subjectification of regional stakeholders, the formation of a regional stakeholder community, the singularization of a proposition for regionalization, the establishment of recognized regional spokespersons and finally - the delegation of the proposition for regionalization into more stable and durable sociomaterial forms.

Still there are important divergences between the cases in themselves, and also between the individual cases and the sketched conceptual model. One such divergence concerns the sketched temporality of the conceptualized phases. For when examining the cases, it becomes apparent that these sketched phases are not neatly separated discrete stages, but rather blend into each other - both temporally and thematically. For instance, within the emergence-phase, the processes of articulating common concerns and the processes of regional stakeholder subjectification to a large degree appear to entail two sides to the same coin, in the form of a co-constitutive dynamic. But with regards to the relationship between the formation of a stakeholder community and the singularization of the proposition for regionalization, the link is not as clear, which also goes for the relationship between the mechanisms of recognized spokesperson formation in relation to the achievement of taken-for-granted reality status for a region, not to mention the cross-linkages between the different mechanisms which in this model have been placed in different phases of regionalization. 
With regards to the temporal relation between the conceptualized phases, particularly the stabilization phase often appears to overlap with the other two phases to such a degree in the cases that it becomes questionable whether the mechanisms described under this phase can rightfully be conceptualized as a separate phase - which is perhaps not so surprising given the nature of these processes. For instance, the so-called singularization of the proposition for regionalization appears to occur all along in some of the studied processes towards regionalization, albeit not in a stable streamlining flow but rather in bursts and spurts. Further, the supposed singularization of a regional essence and articulated regional interests in the form of coherence is not particularly pronounced, or at least not in any way forced, in any of the studied cases - but rather occurs more indirectly through the construction and selective reproduction/dissemination of shared 'knowledge', in the form of analyses of regional issues and/or patterns and projections for regional futures, or through the indirect codifying ascription through the formatting of particular grant guidelines, etc. Such shared knowledge appears to form an important role in what perhaps could be called the configuration of common ontologies (see Callon, 1998:8). Still, in all of the studied regions, up until present time, many different - sometimes partially connecting, sometimes mutually contradicting - articulations of the regions' interests and essences appear to be in circulation, but where some are obviously more influential or have more traction than others (cf. Lagendijk, 2007). These findings thus highlight the difficulties of achieving complete singularization of a proposition for regionalization, no matter how extensively materialized, and points towards the possibility that at least some degree or margin of multiplicity may at any given time be a 'normal' situation for any proposition for regionalization. This insight thus points towards the conclusion that the coherence and singularity of a proposition for regionalization may be a very situated, more or less temporary and often quite precarious achievement.

Empirical postscript: From the chatter of the multitude to the singular voice of the coherent region... and sometimes back again

If we do not subscribe to some form of naive end of history-thesis an important question to ask concerns what happens at the moment $n+1$, when a proposition for regionalization has painstakingly passed through all the stages of the sketched model. Does the 'well-constructed' region now simply settle into a non-negotiable and non-reversible reality? Has the once so fragile proposition now become transposed into such a durable and hermetically sealed black-box that it from now and forever on will be taken for granted as a natural and seemingly self-evident region? 
As noted above, the BSR is still in every way far from reaching such a status, and may still - for all we know - come out the other end still-born or arrested in its development. With regards to Øresund, a little more than a decade after the grand opening of the towering bridge the proposition for regionalization which to a large extent always posited the essence of the region to be cross-border links and commuting has remained solid enough in wide policy circles to remain a "simple" unchallenged truth (Ek, 2006). Or rather, even though the region still contains not completely neutralized centreperiphery lines of conflict, challenges against it have been easily marginalized. An important explanation for this is that the a large share of the task of holding the region together was delegated to the faithful lieu-tenant ('place-holder' in French) of the Øresund bridge, which daily facilitates the reality of this "transport monotopia" (Ek, 2006) which thus does not require passionate votes of allegiance anymore, only the non-dramatic daily routine enactment of cross-border flows of goods and traffic. Few except for the odd regional politician or zealous planner really appear to truly passionately care about it anymore, but almost no one would question its mundane existence as a simple, commonplace and non-dramatic phenomenon - well-integrated into the rhythms of everyday life. A (rather dull) taken for granted reality which simply is taken into account with all the other entities and actors that people the world.

With the Mälardalen-case the situation appears to have turned out a little differently. Towards the end of the 2000's the proposition for regionalization seemed to be on-course towards yet another stage of institutionalization as it was on a trajectory towards becoming formalized as a Swedish state spatiality in the form of a new type of regional administrative entity with quite far-reaching legally codified rights of taxation and political representation. But in February 2007 a committee consisting of representatives from all the political parties in the Riksdagen (Swedish parliament) after four years of investigation handed in their proposal for a new formal regional administrative organization for the country. In the final report of the committee it is stated that Mälardalen must be considered to be a functionally and politically well-integrated region, the development of which is of crucial national interest with regards to economic growth and competitiveness. But then, as a bombshell, the committee suggests that the region should not be granted the status of an official administrative region, arguing that a formalized Mälardalen region would cover such a great proportion of the national population that it would generate grave national economic and political asymmetries. To prevent such asymmetries from occurring the committee suggests a population cap of two million inhabitants for administrative regions, which effectively blocks the official formation of a Mälardalen region, which would land at a population between two and a half and three million inhabitants. 
Following the committee report the Swedish government invited counties to come together 'from below' and hand in proposals for mergers into larger administrative regions, with the implicit understanding that a full Mälardalen region would not be allowed. This sudden turn of events put the counties surrounding Lake Mälaren in a very awkward position as they had now for a decade and a half tied their fate to the formation of a common, integrated regionalization with Stockholm, the economic engine of the country. What were they to do now, when this road forward appeared to be blocked by a powerful actor, the national government? An outburst of nervous answers rapidly ensued, all of them in different ways contributing to the consequent unwrapping and destabilization of a regionalization that but moments before had appeared so solid and self-evident - a seemingly stable singularity that now rapidly began to blur into multiplicities. Only recently taken for granted truths and settled alliances were suddenly opened up for reconsideration. In a debate article in a regional daily some elected representatives from different administrative levels of one of the counties ask themselves: is Stockholm really a necessary component of an integrated Mälardalen region? Maybe the other Mälardalen counties only have partially overlapping interests with Stockholm - but more in common together? A flurry of new maps were produced and circulated, with various versions of Mälardalsregionen of diverging territorial scope and quite a few without any form of Mälardalen region at all, but with the Mälardalen counties split between a number of alternative administrative regions.

The county administrative board of Södermanland, one of the Mälardalen counties bordering Stockholm, put their cards on the table and unilaterally formally apply with the county of Stockholm to form a new region together, implicitly excluding some of the other Mälardalen counties. Stockholm quickly shrugged off this rather brusque invite as the political majority of the county remains closely tied and loyal to the national government and their informal wish to completely exclude Stockholm from any newly formed administrative regions. In apparent desperation the Södermanland county politicians then made a complete turnaround to instead propose a merger with two other Mälardalen counties, excluding Stockholm - but the initiative was quickly aborted following a threatened revolt by the county's own constituent municipalities. After the passing of the deadline posted by national government in February 2012 it turned out that no formal application for new administrative regions involving any of the Mälardalen counties had been filed. There would be no formal Mälardalen region either with or without Stockholm.

One way to analyze the thwarted formalization of Mälardalen into an officially recognized administrative region would be to see this as a deathblow to the process of regionalization which blocks the route 
towards further institutionalization, leaving the region hanging in a limbo as some form of abortive or failed region, similar to the BSR in the mid 90ies. But not necessarily. From a different perspective, it might also be seen as a proof of strength; for even though the Mälardalen 'Leviathan' did not become a recognized state spatiality, neither was it formally territorially broken up and fractured into other, competing constellations (e.g. with some of the counties but excluding Stockholm). So in a different way, if we as researchers do not just stare ourselves blind on formal state recognition as the only trait of a 'real' region, but rather track all the heterogenous materials and linkages that carry and stabilize the proposition for regionalization, we might in this case come to see that the Leivathan of the Mälardalen region perhaps even came out strengthened from this trial of force. For in the process, no actor questioned whether a Mälardalen region really existed (except for the odd marginalized regional geographer). The disagreement, which then appeared to settle, rather concerned its properly defined essence and boundaries. Instead, a choir of disparate voices - even including the skeptical parliamentary committee - kept repeating as in unison: it is a region, tied together by mutual interests, economic dynamics and (rail-based) commuter flows.

As Metzger \& Schmitt (2012) have previously argued, it thus appears important not confuse degrees of administrative formalization of regions with degrees of durability or staying power. What rather appears to distinguish a well institutionalized - that is, well stabilized - regional Leviathan is not necessarily the formal hallmark of a recognized state spatiality. Rather, having travelled widely and become delegated to both heterogeneous and durable forms and materials it holds firm in its recognized existence against fundamental challenges. Once reaching such a degree of durability, the Leviathan can even afford itself to mutate in parts, to slowly change shape, and shift nuances at the edges without rupturing or falling apart (Callon \& Latour, 1981: 285). And so it also does in the case of Mälardalen. Where the parliamentary committee in 2007 discussed four counties as composing a "functional region" in Mälardalen - all directly bordering Lake Mälaren, in 2012 the webpage of Mälardalsrådet now lists five counties, one not directly bordering the lake, as composing the territory of the region. Further, in the new infrastructure development process initiated for the Mälardalen region, as many as seven counties are directly involved. At the same time the discussion goes on: maybe the region is not really fundamentally held together by rail commuting links but by roads ('more money to roads, less to tracks!')? Maybe what holds it together is that it is a "knowledge region" and/or an "entrepreneurial region"? The search for the essence of the region goes on, but not once is its status as a firm reality questioned in this process. Even if there is no final agreement on what the region fundamentally is, it is incessantly repeated over and over again that it nevertheless is. 


\section{Concluding discussion}

A central purpose of this paper has been to explore new ways of studying and conceptualizing spatial entities such as regions which do not take the existence of such entities for given or as independent of human subjectivity, but which neither reduces them to the status of pseudo-real mirages or collectively reified delusions. Through drawing upon inspiration from so-called Actor-Network Theory an attempt has been made to skirt the often recurring question in regional studies: is the region constructed or not? Instead-questions are raised concerning how regions sometimes can be constructed in such ways that they may become taken for granted as seemingly natural reference points in the world. This thus entails a non-denunciatory approach, the purpose of which is not to debunk regions as unwarranted reifications, but which instead conceptualizes spatial entities such as regions as amalgamated relational assemblages composed of both human and non-human components, which are dependent on the human component for their existence but also have a power of agency to guide or even format human action, thus making a definite difference in the world as an actor or 'actant' in its own right in the form of a collective macro-actor or 'regional Leviathan' (cf. Paasi, 2010). From such a perspective, the formulation of a proposition for regionalization can be seen as an attempted operation of capture, connection and organization where regions emerge as seemingly natural and taken-for-granted spatialities by way of institutionalization, which in this case does not necessarily refer to their formal recognition as state spatialities but rather the extent to which propositions for regionalization are transposed into heterogeneous material forms that are more durable than fleeting words - such as transport infrastructure, land-use patterns, financial support schemes and cooperation organizations or legal code - which all in different ways may contribute to generating the region as a taken for granted mundane reality, a 'black box'.

By paying explicit attention to the initial stages of the processes through which regions emerge in the form of vague propositions for regionalization, and then tracking these processes through gradual stages of stabilization, we might learn to treat spatial entities not as either real or constructed, but instead come to appreciate that they are both very real and constructed at the same time - and further that the more sturdily constructed they are, the more real they become - sometimes to the degree that their existence in the world becomes naturalized and widely taken for granted. One possible way of making these processes sensible is by conceptualizing regions-in-becoming as publics-in-stabilization. Even this particular approach can of course be operationalized in numerous ways, but has within this paper been approached through the sketching of a rough model comprising three phase - or perhaps rather: 
interlocking mechanism - of increasing degrees of stabilization ranging from the initial articulation of shared regional concerns, up through the formulation of vague propositions for regionalizations that might or might not 'travel' and 'stick', to finally sometimes result in the institutionalization of a widely recognized and taken for granted region. The stages of these processes appear to be entangled and overlapping in both time and content, even though roughly consecutive in analytical abstraction.

Neverheless, we must not fall to the temptation to write Whiggish histories of regionalization. For even if regions, when they reach an advanced stage of institutionalization, might appear as wholly irreversible completely natural or organic structured coherences, we must not forget that they are always the outcome of long processes of singularization and stabilization that never have any guaranteed outcomes. Therefore, it is important to always see regionalization as a dynamic process, where the successful stabilization of recognized regions are more exceptions than the rule, but where the regional entities that have been successfully (temporarily) stabilized are often easier to perceive, grasp and take for given than regions-in-becoming in various stages of regionalization.

Since regionalization processes thus can and often are challenged, halted some observers have come to conclude that regions must be seen as fundamentally contested entities. But in the light of the empirical material presented in the paper, perhaps this remark must be moderated a bit to conclude that regions appear to be prone rather than preordained to unpredictability and contestation. Sometimes there is wide agreement on what the region is, sometimes there are diverging versions of the region that for a longer or shorter duration of time may coexist side by side - indicating that regions are not 'by nature' contested. Rather, they sometimes "may hang together here, in this instance, for this purpose, while it is also in tension, there, a little later, in relation to another issue" (Mol, 2010: 260) - their essence never fully to be settled once and for all, but neither subject to a state of constant controversy. Thus, the state of ontological multiplicity of only partially connecting propositions for regionalization circulating at any given time under the same proper name does not always appear as a problem or a challenge. Still, there may occur points where a seemingly powerful regional Leviathan may face a direct challenge so forceful that the alignment of multitudes of actors into a seemingly coherent whole rapidly may start to come apart and begin to turn into a Colossus on clay feet or a chattering Tower of Babel. Alternative versions of the region and competing spatialities which may have been subdued and marginalized for a period by the power of the Leviathan again begin to proliferate, at which moment the Leviathan may be fully on the verge of collapse. Or again - yet still there, but just temporarily somewhat fuzzier, multiple and unclear in its contours and essence until it regains its composure. From this perspective, it might thus 
perhaps be easier to conceptualize the regional Leviathan as a trajectory more than a stable 'thing', sometimes seemingly converging into one bold straight arrow towards a clear future, while at other times only consisting of a more or less consistent, coherent and aligned bundle of only partially crisscrossing capillaries, sometimes clinging around each other but often shooting off branches into idiosyncratic directions (cf. Massey, 2005; Hillier, 2007).

In conclusion, it is important to again clarify that the conceptual model presented in this paper in no way pretends to constitute some form of general or all-covering theory of regionalization. Rather, the ambition is somewhat more limited and instead entails an attempt to argue and demonstrate that the proposed conceptual framework might help scholars shed light on the historically contingent character of regions and some of the processes through which they sometimes come to appear otherwise. The point here isn't that regions are somehow conjured 'out of the blue'. To the contrary, they are formed in the middle of a world always already ongoing, where every outcome isn't equally likely, but often due to factors beyond the grasp of the moment of action. A world where material structures beckon to be captured and connected through discourse, and fleeting words reach towards being transposed into concretized vestiges of bricks and asphalt. Where the fluctuation between these two desires generates a force-field wherein spatial entities never emerge as a fully linear process ex nihilo, but rather as a fluctuation of creative destruction or a series of trajectories of spatial organization composed out of temporary stabilizations and alignments of ever mutating patterns of spatiotemporal change where "some space-times are more durable" while other "flicker out of existence" (Thrift, 2004) and where we, taking our cue from Harvey (1996), may come to see any perceived spatial "permanences" as always dependent on the processes that create, sustain and dissolve them.

This paper ends here - but with a sense of that so much must be left unsaid, a stammering 'and, and, and...'. So much work yet to be done for which this paper can be but a frustrating vignette. The task ahead lies in getting even closer up to regionalization in action and in situ to really get a lively sense and feeling for the sweatiness and messiness of the birth pangs and growing pains of regional Leviathans. To rub up against the twin pincers of double articulation at work in various stages of concretization -at one at the same time generating the form and essence of the region in becoming. To put an ear directly against the initially faint but increasingly loud murmur being heard as vague publics begin to solidify into recognizable territorial stakeholder communities: "the region is... The region can be... The region must be...", in close attention tracing the chiasmic ontological transformations that occur in these processes from fleeting but passionate words to hard concrete and cold steel, and then back again. 


\section{Footnotes}

[1] Of course, lest we forget, there is of course always also an "outside on the inside", consisting of those elements in geographic proximity that are deemed not to qualify for regional identity, and which thus are deemed alien, and not belonging to the region proper (Painter, 2008). See also Healey's (2007) discussion on foregrounding/backgrounding.

[2] Nevertheless, the perspective on regional becoming presented here is still (partially) compatible with both established state-theorist and Marxist conceptualizations of the region, given the caveat that a priori privilege or 'determining in the last instance'-status is granted to neither the mechanism of state sovereignty, nor to capital accumulation - but that these are seen as examples of the heterogeneous mechanisms (albeit potentially very influential such) that may contribute to the process of regionalization.

[3] I wish to thank one of the anonymous referees for pointing out the unintentional but of course not entirely coincidental parallel between the model for understanding regionalization proposed in this paper and Latour \& Woolgar's model for tracing the construction of a fact (Latour \& Woolgar, 1979: 82). Along the same lines it can be noted that, perhaps even more distinctly, the model presented here also shares some salient features with Latour's (2007)suggested conceptualization of the stages of development of political issues.]

[4] A parallel can here be drawn to Benedict Andersons celebrated account of the emergence of the nation as an "imagined community" (Anderson, 1983/2006) which he traces as a both discursive and material process, e.g. through the agency of the printing press and other communication and transportation technologies.

[5] The most extensive examination of the regionalization of Øresund is probably Ek (2003), a text which unfortunately has not been translated to English. 


\section{References}

Albrechts, L. (2010) More of the same is not enough! How could strategic spatial planning be instrumental in dealing with the challenges ahead? Environment and Planning B 37.6, $1115-1127$.

Allen, J., Massey, D. \& Cochrane, A. (1998) Rethinking the region. London, Routledge.

Anderson, B. (1983/2006) Imagined communities: reflections on the origin and spread of nationalism. (Rev. ed.) London, Verso.

Barnes, T. J. (2002) Performing economic geography: two men, two books, and a cast of thousands. Environment and Planning A 34.3, 487-512.

Berg, P. O. (2001) The Summoning of the Öresund Region. In B. Czarniawska \& R. Solli (eds.) Organizing metropolitan space and discourse. Liber, Copenhagen.

Berg, P. O., A-L Laursen and O. Löfgren (2000) Invoking a transnational metropolis: the making of the $\emptyset$ Øresund Region. Studentlitteratur, Lund.

Braithwaite, J. (2008) Regulatory capitalism: how it works, ideas for making it work better. Edward Elgar, Cheltenham.

Callon, M. \& B. Latour (1981) Unscrewing the big Leviathan: how actors macrostructure reality and how sociologists help them to do so. In K. Knorr-Cetina \& A. V. Cicourel (eds.) Advances in social theory and methodology: Toward an integration of micro and macro-sociologies. Routledge \& Kegan Paul, London.

Callon, M. (1998) 'Introduction: The embededdness of economic markets in economics', in Callon, M. (ed.) The Laws of Markets, Blackwell, Oxford.

Callon, M. and J. Law (1995) Agency and the hybrid «Collectif». The South Atlantic Quarterly 94.2, 481507.

Callon, M. and J. Law (2004) Introduction: absence-presence, circulation, and encountering in complex space. Environment and Planning D 22.1, 3-11.

Callon, M. and J. Law (2005) On qualculation, agency, and otherness. Environment and Planning D 23.5, 717-733.

Cooren, F. (2010) Action and agency in dialogue. John Benjamins, Amsterdam.

Corvellec, H. (2001). The New Rhetoric of infrastructure projects. In B. Czarniawska \& R. Solli (eds.) Organizing metropolitan space and discourse. Liber, Copenhagen.

Czarniawska, B. and G. Sévon (2005) Translation is a vehicle, imitation its motor, and fashion sits at the wheel. In B. Czarniawska \& G. Sévon (eds.) Global ideas: how ideas, objects and practices travel in the global economy, Liber \& CBS Press, Malmö, pp. 7-12. 
Deleuze, G. \& Guattari, F. (1987) A thousand plateaus: capitalism and schizophrenia. Minneapolis, University of Minnesota Press.

Donaldson, A. (2006) Performing regions: territorial development and cultural politics in a Europe of the Regions. Environment and Planning A 38.11, 2075-2092.

Ek, R. (2003) Öresundsregion - bli till!: de geografiska visionernas diskursiva rytm. Diss. Lund : Lunds universitet, 2003. Lund.

Ek, R. (2006) The Öresund region: six years with the bridge. Keynote address delivered at the Nordic Network of the Regional Studies Association conference in Balestrand, Norway, 4- $5^{\text {th }}$ of May 2006. Available from the author upon request.

Featherstone, D. (2007) Skills for heterogeneous associations: the Whiteboys, collective experimentation, and subaltern political ecologies. Environment and Planning D 25.2, 284-306.

Gibson, K. (2001) Regional subjection and becoming. Environment and Planning D 19.6, 639-667.

Gregson, N. and G. Rose (2000) Taking Butler elsewhere: performativities, spatialities and subjectivities. Environment and Planning D 18.4, 433-452.

Haraway, D.J. (2008) When species meet. University of Minnesota Press, Minneapolis.

Harvey, D. (1996). Justice, nature and the geography of difference. Blackwell, Oxford.

Healey, P. (1998) Building institutional capacity through collaborative approaches to urban planning. Environment and Planning A 30.9, 1531-1546.

Healey, P. (2006) Collaborative planning: shaping places in fragmented societies. Palgrave Macmillan, Basingstoke.

Healey, P. (2007) Urban complexity and spatial strategies: towards a relational planning for our times. Routledge, London.

Hillier, J. (2007) Stretching beyond the horizon: a multiplanar theory of spatial planning and governance. Ashgate, Aldershot.

Hobbes, T. (1997) Leviathan. Touchstone, New York. Originally published in 1651.

Jensen, O.B. \& Richardson, T. (2004) Making European space: mobility, power and territorial identity. London, Routledge.

Jessop, B. (2006) Spatial fixes, temporal fixes and spatio-temporal fixes. In N. Castree \& D. Gregory (eds.) David Harvey: a critical reader. Blackwell, Oxford.

Lagendijk, A (2007) The Accident of the Region: A Strategic Relational Perspective on the Construction of the Region's Significance. Regional Studies 41.9, 1193-1208. 
Lagendijk, A. and J. Cornford (2000) Regional institutions and knowledge: tracking new forms of regional development policy. Geoforum 31.2, 209-218

Latour, B. (1987) Science in action: how to follow scientists and engineers through society. Harvard University Press, Cambridge, Mass.

Latour, B. (1988) The pasteurization of France. Harvard University Press, Cambridge, Mass.

Latour, B. (1999) Pandora's hope: essays on the reality of science studies. Harvard University Press, Cambridge, Mass.

Latour, B. (2003) What if we Talked Politics a Little? Contemporary Political Theory 2:,143-164.

Latour, B. (2004) Politics of nature: how to bring the sciences into democracy. Harvard University Press, Cambridge, Mass.

Latour, B. (2005a) From Realpolitik to Dingpolitik: or how to make things public. In B. Latour \& P. Weibel (eds.) Making things public: atmospheres of democracy. MIT Press, Cambridge, Mass.

Latour, B. (2005b). Reassembling the social: an introduction to actor-network-theory. Oxford University Press, Oxford.

Latour, B. (2007). Turning Around Politics: A Note on Gerard de Vries' Paper. Social Studies of Science $37(5), 811-820$.

Latour, B and E. Hermant (2006) Paris: Invisible city. Available at: http://www.brunolatour.fr/sites/default/files/downloads/viii_paris-city-gb.pdf (Accessed May 31 ${ }^{\text {st }}$ 2012).

Latour, B. and S. Woolgar (1979) Laboratory life: the social construction of scientific facts. Sage, Beverly Hills.

Law, J. (1992) Notes on the Theory of the Actor-Network: Ordering, Strategy and Heterogeneity. Systems Practice 5, 379-393.

Law, J. (2004) Matter-ing: Or How Might STS Contribute? [WWW- document]. Centre for Science Studies, Lancaster University. http://www.lancs.ac.uk/fass/sociology/papers/law-matter-ing.pdf (Accessed October 10th 2011).

Law, J. (2007) Actor Network Theory and Material Semiotics [WWW-document]. Centre for Science Studies, Lancaster University. http://www.heterogeneities.net/publications/Law2007ANTandMaterialSemiotics.pdf (Accessed October 10th 2011).

Law, J. (2009) Collateral realities. Centre for Science Studies, Lancaster University. http://www.heterogeneities.net/publications/Law2009CollateralRealities.pdf (Accessed October 10th 2011). 
Law, J. and A. Mol (2001) Situating technoscience: an inquiry into spatialities. Environment and Planning D 19.5, 609-621.

Lehti, M. (2009) Baltic Region in Becoming: from the Council of the Baltic Sea States to the EU's Strategy for the Baltic Sea Area. Lithuanian Foreign Policy Review 22: 9-27.

Lyck, L. and P. O. Berg (1997) The Øresund region building. Nyt fra samfundsvidenskaberne, Copenhagen.

MacLeod, G. and M. Jones (2001). Renewing the geography of regions. Environment and Planning $D$ 19.6, 669-695.

Marres, N. S. (2005a) No issue, no public: democratic deficits after the displacement of politics. Department of Philosophy, University of Amsterdam, Amsterdam. Doctorate thesis.

Marres, N. S. (2005b) Issues spark a public into being: A key but often forgotten point of the Lippmann Dewey debate. In B. Latour \& P. Weibel (eds.) Making things public: atmospheres of democracy. MIT Press, Cambridge, Mass.

Massey, D.B. (2005) For space. London, SAGE.

Metzger, J. and P. Schmitt (2012) When soft spaces harden: The EU Strategy for the Baltic Sea Region. Environment and Planning A 44(2), 263-280

Mol, A. (1999) Ontological politics: a word and some questions. In J. Law \& J. Hassard (eds.) Actor Network Theory: and after. Blackwell, Oxford.

Mol , A. (2010) Actor-Network Theory: Sensitive terms and enduring tensions. Kölner Zeitschrift für Soziologie und Sozialpsychologie 50.1, 253-269.

Munk, A. K. and S. Abrahamsson (2012) Strategy and tactics on the ontopolitical battlefield. Science Studies 25 (1), 52-70.

Murdoch, J. (2006) Post-structuralist geography: a guide to relational space. London, SAGE.

Olsson, G. (2007) Abysmal: a critique of cartographic reason. Chicago, IL, University of Chicago Press.

Paasi, A. (1986) The institutionalisation of regions: a theoretical framework for understanding the emergence of regions and the constitution of regional identity. Fennia 164.1, 105-146

Paasi, A. (2001) Europe as a Social Process and Discourse: Considerations of Place, Boundaries and Identity. European Urban and Regional Studies 8.1, 7-28.

Paasi, A. (2002a) Place and region: regional worlds and words. Progress in Human Geography 26.6, 802811. 
Paasi, A. (2002b) Bounded spaces in the mobile world: Deconstructing 'regional identity', Tijdschrift voor Economische en Sociale Geografie 93.2, 137-148.

Paasi, A. (2010) Regions are social constructs, but who or what 'constructs' them? Agency in question. Environment and Planning A 42.10, 2296 - 2301.

Paasi, A. (2012) Regional Planning and the Mobilization of 'Regional Identity': From Bounded Spaces to Relational Complexity. Regional studies ahead of print publication.

Painter, J. (2008) Cartographic anxiety and the search for regionality. Environment and Planning A 40.2, 342-361.

Stengers, I. (2011) Thinking with Whitehead: a free and wild creation of concepts. Harvard University Press, Cambridge, Mass.

Stenlås, N. (2008) Visionen om Stockholm-Mälarregionen. In E. Westholm, J. Amcoff, J. Falkerby, M. Gossas \& N. Stenlås (eds.) Regionen som vision: Det politiska projektet Stockholm-Mälarregionen. SNS Förlag, Stockholm.

Syssner, J. (2006) What kind of regionalism?: regionalism and region building in northern European peripheries. Diss. Linköping : Linköpings universitet, 2006. Frankfurt, Peter Lang.

Thrift, N. (1996) Spatial formations. London: Sage Publications.

Thrift, N. (2004) 'Summoning life', in P. Cloke, P.Crang and M. Goodwin (eds.) Envisioning human geographies. Arnold, London.

Westholm, E., J. Amcoff, J. Falkerby, M. Gossas and N. Stenlås (2008) Regionen som vision: det politiska projektet Stockholm-Mälarregionen. SNS Förlag, Stockholm.

Whatmore, S. (2002) Hybrid geographies: natures, cultures, spaces. London: SAGE. 
Table 1 Phases of development and stabilization for three contemporary North $\epsilon$

Regionalization

Emergence phase

Territorially framed common concerns

Regional stakeholder subjectification

\begin{tabular}{|c|c|}
\hline & $\begin{array}{l}\text { local identities and sectoral } \\
\text { interests }\end{array}$ \\
\hline Stabilization phase & 1990s-mid 2000s \\
\hline Stakeholder community & $\begin{array}{l}\text { Multiple networks and } \\
\text { organizations }\end{array}$ \\
\hline Singularization dynamic & $\begin{array}{l}\text { Yes, for instance through } \\
\text { generation of shared } \\
\text { knowledge base }\end{array}$ \\
\hline Institutionalization phase & $\begin{array}{l}\text { late 1990s-2000s } \\
\text { Yes, primarily Mälardalsrådet }\end{array}$ \\
\hline Spokesperson formation & (founded 1992) \\
\hline Examples of recognized outcomes & Transport infrastructure \\
\hline
\end{tabular}

Mälardalen region

Subnational

late 1980s-early 1990s

Water management, transport, housing, business promotion

Primarily in relation to other

parts of country, entrenched

local identities and sectoral
Geographic reach

19 
